\title{
A KRAKÓW TO... MIASTO ORGANIZACJI I RUCHÓW OBYWATELSKICH
}

\begin{abstract}
And the Cracow is... the City of NGO's and Civic Movements

The paper object is to analyze the differences between the methods used by NGOs and civic movements, in order to influence the territorial development trends in Cracow. The text discusses methods of those, which shaped the directions of development of Cracow, on the background of the theory of life cycle of the organization.
\end{abstract}

Key words: territorial development, NGOs, civic movements, Cracow.

\section{Streszczenie}

Przedmiotem artykułu jest analiza różnic w metodach stosowanych przez organizacje pozarządowe i ruchy obywatelskie w celu wpływania na kierunki rozwoju terytorialnego Krakowa. Omówiono sposoby działania podmiotów kształtujących kierunki rozwoju Krakowa w ostatnich latach, na tle teorii cyklu życia organizacji.

Słowa kluczowe: rozwój terytorialny, organizacje pozarządowe, ruchy obywatelskie, Kraków

\section{Wstęp}

Kiedy śledzimy połączenia między procesami składającymi się na rozwój miasta, zaskakuje mnogość wzajemnych zależności. Analizując informacje na temat rozwoju sieci transportowej, w naturalny sposób dotykamy tematyki rozbudowy kolejnych dzielnic miasta. Rozbudowa dzielnic prowadzi nas do refleksji nad rewizją funkcji pełnionych przez te obszary. Gdy rozmawiamy o nowych funkcjach fragmentów miast, dotykamy kwestii związanych ze sposobem wykorzystywania ich przez mieszkańców. Idąc tym tropem, finalnie natrafiamy na kwestie związane z oczekiwaniami i potrzebami użytkowników, z którymi kształt przestrzeni miejskiej powinien korespondować. 
Celem niniejszego artykułu jest zobrazowanie różnic występujących w sposobach i metodach, jakie stosują organizacje pozarządowe i ruchy obywatelskie w celu aktywnego wpływania na rozwój terytorialny Krakowa. Rozpoznane różnice zostały opisane zależnie od fazy cyklu życia organizacji, na podstawie przykładów trzech podmiotów działających na terenie Krakowa: Kolektywu Modraszek, Inicjatywy Kraków Przeciw Igrzyskom oraz Stowarzyszenia Krakowski Alarm Smogowy. Dla realizacji celów opracowania posłużyły: analizy materiałów prasowych, materiałów własnych organizacji oraz bezpośrednie uczestnictwo autorki w wydarzeniach organizowanych przez powyższe podmioty.

\section{Uczestnicy procesów planowania rozwoju miast}

Złożoność problematyki planowania rozwoju miast w naturalny sposób pociąga za sobą wielość podmiotów, które współuczestniczą w wyznaczaniu kierunków rozwoju terytorialnego, a ostatecznie także jego strategii. Literatura przedmiotu proponuje wiele różnych ujęć tego zagadnienia, natomiast z punktu widzenia podjętych rozważań szczególnie wartościowe stają się dwa opisane poniżej.

Pierwsza typologia proponuje podział na:

- instytucje odpowiedzialne za opracowanie planów;

- organizacje zainteresowane (zlokalizowane lub prowadzące działalność na terytorium objętym planem);

- członków wspólnot, niezorganizowanych lub zrzeszonych w lokalne komitety [Noworól, 2007: 150].

Grupa instytucji obejmuje w tym ujęciu głównie władzę i administrację publiczną, wspierane przez doradców i zespoły eksperckie. Druga grupa podmiotów zawiera w sobie nie tylko organizacje biznesowe, ale także wszystkie sformalizowane rodzaje działalności pozarządowej i instytucje publiczne. Ostatnia grupa uczestników to podmioty rozproszone, których działania mają charakter doraźny. Ich celem najczęściej nie jest przejęcie bezpośredniej odpowiedzialności za organizację i przeprowadzenie zmian, ale ich ukierunkowanie w pożądany sposób lub zasygnalizowanie istnienia społecznie ważnego aspektu rozwoju.

Druga typologia bazuje na podobnym podejściu, inaczej jednak rozgraniczając uczestników procesów planowania strategii rozwoju. Wskazuje ona na istnienie:

- grupy kreującej strategię (zespoły eksperckie, badawcze, planistyczne);

- zespołu realizującego (władze regionalne na szczeblu samorządowym i rządowym, podmioty gospodarcze, okołobiznesowe oraz przedstawiciele samorządu lokalnego);

- gremium obserwującego (organizacje pozarządowe, media oraz partie polityczne) [Heffner, 2008: 160].

Opis ten przywodzi na myśl Monteskiuszowski trójpodział władz, który w tym kontekście nadaje grupie gremium obserwującego ważną rolę społecznej oceny planowanych działań prorozwojowych. Zadanie to od lat realizują przedstawiciele mediów. Coraz częściej i chętniej widzą się w tej roli również podmioty trzeciego 
sektora; niekiedy kontrolowanie działań zespołów realizujących staje się głównym przedmiotem ich zainteresowania. Jednocześnie takie rozgraniczenie grup współdziałających w zakresie kształtowania i wykonawstwa przyjętej strategii staje się mocnym zaakcentowaniem konieczności ich dopełniającego się współistnienia. Wagę świadomości tego splotu podkreśla między innymi prof. Andrzej Wiatrak, zwracając uwagę, że „strategia rozwoju gminy jest realizowana dla mieszkańców wspólnoty, dlatego też niezbędne jest ich włączenie się w przygotowanie i ustalanie kierunków przyszłych działań, które będą łączyć, a nie dzielić społeczeństwo" [Noworól, 2007: 149].

\section{Udział obywateli w procesach kształtowania rozwoju}

Władze lokalne dysponują wieloma narzędziami aktywizowania innych podmiotów w procesie kształtowania strategii rozwoju; korzystają z konsultacji społecznych, kampanii reklamowych i informacyjnych, organizują debaty i konferencje prasowe, odpowiadają na postulaty i wnioski stron. Wachlarz możliwości pozostający do dyspozycji obserwatorów jest równie bogaty, co więcej, rozwija się w sposób dynamiczny. Udział obywateli w procesach decyzyjnych dotyczących rozwoju miasta jest realizowany poprzez [Noworól, 1998]:

1. działalność przedstawicieli lokalnych mediów - ich zaangażowanie jest podwójne: $\mathrm{z}$ jednej strony są reprezentantami interesów swojego pracodawcy, a z drugiej strony najczęściej sami są mieszkańcami terenów objętych konkretnym planem rozwoju;

2. działalność liderów lokalnych społeczności - skupiają wokół siebie ludzi chcących działać na rzecz konkretnego rozwiązania; dla osób niezrzeszonych identyfikacja z postacią lidera czy otwarte wspieranie działań jego zwolenników jest formą manifestacji postawy wobec danego tematu;

3. działalność stowarzyszeń i fundacji - są one podmiotami o określonym statusie prawnym, co umożliwia działania przy wykorzystaniu formalnych dróg i narzędzi. Grupa ta już jest bardzo liczna; na terenie samego Krakowa istnieje 1588 zarejestrowanych stowarzyszeń (w tym 84 o statusie organizacji pożytku publicznego) oraz 1248 fundacji (w tym 99 o statusie organizacji pożytku publicznego) [www.bazy.ngo.pl]. Organizacje pożytku publicznego, tak zwane OPP, stają się na tyle istotne dla podjętych rozważań, iż mogą być wspierane przez podatników w ramach mechanizmu przekazywania jednego procentu podatku dochodowego. Jest to forma wsparcia finansowego, ale również identyfikacji i dopingowania działań konkretnych podmiotów;

4. nieformalne grupy nacisku (komitety protestacyjne) - grupa nacisku, nazywana też grupą interesu, jest zbiorowością połączoną wspólnymi celami, która wpływa na politycznych decydentów, by realizować swoje interesy [Srokosz, 2007]. W tym jednak przypadku nieformalność jest ich najważniejszą cechą. Nie mają struktury wewnętrznej, określonej licz- 
by uczestników, zazwyczaj nie posiadają siedziby ani budżetu. Powstają w odpowiedzi na konkretne działania władz, wyrażając swoje niezadowolenie z obranego kierunku decyzji, często przedstawiając swoje żądania i postulaty. Ich istnienie zazwyczaj kończy moment realizacji postulatów, ich porzucenia bądź dezaktualizacji;

5. towarzystwa miłośników - grupy działające na podobnych zasadach do stowarzyszeń; ich najbardziej charakterystyczną cechą jest skupianie osób zainteresowanych i wyrażających troskę o konkretne zagadnienie, np. Towarzystwo Miłośników Historii i Zabytków Miasta Krakowa;

6. lobby - grupa wywierająca wpływ na organy władzy przy użyciu metod i narzędzi zgodnych z prawem; ich celem jest uzyskanie korzystnych dla swoich interesów rozstrzygnięć, które to rozstrzygnięcia są w mocy administracji państwowej [Srokosz, 2007]. Sam lobbing, jako zjawisko oddziaływania na rządzących, nazywane jest też „rzecznictwem interesu" [Srokosz, 2007: 124] Jest to jedna z najbardziej profesjonalnych metod odziaływania obywateli na procesy decyzyjne dotyczące rozwoju terytorialnego.

Powyższe metody oddziaływania należy uzupełnić o zyskujące coraz większą popularność narzędzia elektroniczne. Mowa tu o dwóch kanałach dających duże możliwości wpływania na rozwój terytorialny - mediach społecznościowych oraz crowdfoundingu.

Media społecznościowe dały szansę niespotykanego dotąd przyspieszenia obiegu informacji, płynnej i wielotorowej wymiany danych, która pozwala rozprzestrzeniać idee i opinie de facto bez ograniczeń czasowych i przestrzennych. Według danych GUS w 2015 roku 77,9\% gospodarstw domowych z co najmniej jedną osobą w wieku 12-74 lata miało w domu przynajmniej jeden komputer, a dostęp do Internetu posiadało 75,8\% gospodarstw domowych. Odsetek ten był wyższy o 1,0 p. proc. niż w roku poprzednim [Główny Urząd Statystyczny, 2015]. $\mathrm{W}$ przytaczanym raporcie badacze podkreślają utrzymujące się od wielu lat tendencje wzrostowe tych wskaźników. Internet staje się również miejscem manifestowania niezadowolenia lub wsparcia inicjatyw świata realnego. Korzystamy z tej wirtualnej agory tym chętniej, że daje ona możliwość wyrażania opinii w sposób anonimowy.

Crowdfounding jest metodą gromadzenia funduszy na realizację własnych projektów. Odbywa się to również za pośrednictwem portali internetowych, na których inicjatorzy działań prezentują swoje pomysły, informując, jak dużo pieniędzy muszą zgromadzić, by móc przystąpić do ich realizacji. Zainteresowani użytkownicy mogą dotować wybrane inicjatywy dowolnymi kwotami. Zarówno crowdfounding, jak i media społecznościowe mogą się stać i stają się poważnymi narzędziami w rękach podmiotów mających wpływ na procesy decyzyjne w zakresie zarządzania rozwojem terytorialnym, gromadząc w ten sposób zwolenników oraz zwiększając swoje możliwości działania. 


\section{Metody wpływania na rozwój terytorialny a cykl życia organizacji}

Liczba organizacji pozarządowych i ruchów obywatelskich, które aktywnie działają w przestrzeni miejskiej Krakowa, jest coraz większa. Powstają w odpowiedzi na potrzeby samoorganizacji mieszkańców, ale również jako metoda na zyskanie większej skuteczności w działaniu. Obserwując metody stosowane przez podmioty chcące wpływać na kierunki rozwoju miasta, warto się odnieść do teorii cyklu życia organizacji. Pozwala ona lepiej zrozumieć mechanizm doboru stosowanych przez nie narzędzi, a także dokonać świadomej oceny siły ich oddziaływania na procesy planowania rozwoju. Siła ta zwiększa się wraz ze stopniem rozwoju w cyklu życia organizacji. Koncepcją, która będzie stanowić punkt wyjścia rozważań, jest koncepcja cyklu życia organizacji Roberta E. Quinna i Kima S. Camerona, która wyróżnia cztery jego fazy [Bogacz-Wojtanowska, 2006]:

1. Faza przedsiębiorczości - cechuje się aktywnym gromadzeniem zasobów, mnogością idei i pomysłów, ale również niewielkim planowaniem i koordynacją działań, formowaniem swojej niszy, a także widocznym przywództwem założyciela.

2. Faza kolektywności - jest związana z nieformalną komunikacją i strukturą, dominuje poczucie współpracy, kolektywności i realizacji misji; widoczne są innowacyjne metody działań i duże zaangażowanie członków.

3. Faza kontroli - przynosi stabilizację struktur i formalizację działań. Nacisk kładzie się na skuteczność i utrzymanie swojej pozycji w środowisku, wszelkie aktywności i procedury zyskują instytucjonalny charakter.

4. Faza oceny struktur: odnowa bądź upadek - organizacja ma silną pozycję w środowisku, dopracowane struktury i kanały działania, następuje decentralizacja władzy; organizacja musi się zaadaptować do kolejnych zmian otoczenia i odnowić swoją strukturę lub wygasić działalność.

Doświadczenia współpracy z podmiotami trzeciego sektora, a także obserwacje i analiza danych źródłowych pozwoliły mi również na określenie powtarzających się, charakterystycznych zachowań organizacyjnych. W pierwszej fazie rozwoju częste jest manifestowanie swoich opinii i postaw przez konkretne, rewolucyjne działania, używanie znaków lub atrybutów pozwalających jednoznacznie rozpoznać zwolenników danej postawy. Inicjatywy mają sygnalizować i wskazywać, gdzie istnieje punkt sprzeczności interesów samorządu i społeczności lokalnych. Organizacje stosujące to podejście używają, prawie wyłącznie, narzędzi elektronicznych do informowania o planowanych wydarzeniach, dokumentowania już zakończonych działań oraz komunikacji między uczestnikami. Podejście to wiąże się głównie z realnymi działaniami w świecie rzeczywistym, uczestnictwem w spotkaniach, marszach, wiecach, happeningach, manifestacjach. Element wspólnotowy jest możliwy właśnie dzięki tego rodzaju aktywizacji; członkowie spotykają się w związku z łączącym ich tematem, wspólnie działają na jego rzecz, a dzięki widzialnym atrybutom mogą w łatwy sposób siebie rozpoznać. Najsilniej świadczą o nim niewielkie nakłady organizacyjne, unikanie tworzenia struktur, 
w tym także finansowych, ale również status, wciąż określany jako ruch, inicjatywa czy wspólnota. Podejście to może występować także na początku drugiej fazy życia takiej organizacji.

Faza kolektywności, zazwyczaj, ugruntowuje organizację w sferze postawy aktywnego brania odpowiedzialności za losy społeczności lokalnej i ludzi jako mieszkańców danego terytorium. Obserwujemy wówczas działania o wyższym stopniu formalizacji. Podmioty na tym etapie zaczynają sięgać najczęściej po szeroko zakrojone kampanie informacyjne, korzystają z poparcia osób z zewnątrz organizacji, a także podejmują w pełni profesjonalną polemikę ze stroną miejską. Gromadzą wokół siebie specjalistów i autorytety branżowe, uwiarygodniając i promując $w$ ten sposób zgłaszane postulaty. Procesy te również najczęściej przeprowadzane są w Internecie, za pośrednictwem portali społecznościowych. W zależności od skali przedsięwzięcia możliwe jest sięganie do innych kanałów informacyjnych, na przykład prasy lokalnej. Wszystkie decyzje są nakierowane na gromadzenie poparcia i propagowanie danych idei lub projektów, ale również zwiększanie świadomości osób niezwiązanych bezpośrednio z organizacją. W tym ujęciu tworzenie wspólnoty jako głównego elementu ustępuje miejsca entuzjastycznej realizacji misji i gromadzeniu wokół niej aktywnych i biernych zwolenników. Ten postęp w zakresie formalizowania działań, tworzenia zalążków struktur i pełnowymiarowego zaangażowania utrzymuje się silnie przez całą drugą fazę rozwoju.

W fazie kontroli główne działania organizacji są przekierowywane na uzupełnianie, modelowanie i wspieranie działań samorządowych. Najczęstszymi formami aktywności staje się: opracowywanie raportów, konsultowanie i opiniowanie bieżących działań administracji terytorialnej przez grona eksperckie, lobbowanie na rzecz konkretnych rozwiązań i decyzji (np. przyjęcia uchwały) czy też propagowanie i rozpowszechnianie informacji o działaniach samorządowych. Takie podejście jest najczęściej wynikiem ewolucji organizacji od fazy przedsiębiorczości, nie zaś pierwszą przyjętą postawą; wiąże się z transformacją działań podmiotu, które zmieniają swój rewolucyjny charakter po osiągnieciu sukcesu w realizacji głównych postulatów. O dojrzałości organizacyjnej świadczą liczne przesłanki; najczęściej jest to sięganie po instytucjonalną formę działalności, projektowanie procedur i struktur czy świadome tworzenie sieci kontaktów w środowisku.

Ostatnia faza rozwoju często wiąże się z osłabieniem, zmniejszeniem częstotliwości działań podmiotu. Organizacja ma dobrze rozwinięte struktury wewnętrze, swobodnie funkcjonuje w ramach wybranej formy prawnej. Następuje wyhamowanie tworzenia nowych inicjatyw, przy jednoczesnym utrzymywaniu i kontynuowaniu już istniejących. Często pojawia się tendencja do przekazywania kierownictwa nad działaniami innym organizacjom lub osobom. Część działaczy odchodzi z organizacji, część przyjmuje nowe role. Odrodzenie organizacji jest możliwe tylko dzięki świadomym decyzjom jej członków, najczęściej poprzez zmianę profilu działań lub wytyczenie zupełnie nowych kierunków. 


\section{Działalność organizacji i inicjatyw obywatelskich w Krakowie - wybrane przykłady}

Dla zilustrowania opisywanych procesów i postaw obywatelskich w kontekście wpływania na rozwój terytorialny Krakowa przytoczone zostaną trzy przykłady - inicjatywa obywatelska Modraszek Kolektyw, komitet wyborczy Kraków Przeciw Igrzyskom oraz stowarzyszenie Krakowski Alarm Smogowy. Wszystkie organizacje działają na terenie Krakowa i w ostatnich latach stanowiły ważny i liczący się głos w kształtowaniu kierunków rozwoju terytorialnego miasta.

\section{Modraszek Kolektyw}

Pierwszym z wybranych przykładów są działania inicjatywy obywatelskiej Modraszek Kolektyw. Ruch ten istnieje od 2011 roku i skupiony jest wokół malarki Cecylii Malik. Krakowska artystka postanowiła wesprzeć działalność grupy Zielony Zakrzówek i nagłośnić ich działania. Była ona inicjatorką licznych happeningów, które dotyczyły terenów zalanego wyrobiska wapienia na Zakrzów$\mathrm{ku}$. Teren ten, po zakończeniu prac wydobywczych, $\mathrm{z}$ wolna stawał się miejscem wypoczynku dla mieszkańców okolicznych osiedli, między innymi osiedla Cegielnianego i Ruczaju. Ponieważ zalew sąsiaduje z nieużywanymi poligonami wojskowymi oraz lasem miejskim, w którym znajdują się liczne formacje skał wapiennych (zwanych Skałkami Twardowskiego), jest on uczęszczanym terenem rekreacyjnym. $Z$ tych samych powodów, miejsce to jest bardzo atrakcyjne dla deweloperów, którzy opracowali plan budowy osiedla na tych terenach. Symbolem walki o Zakrzówek stał się modraszek - niewielki błękitny motyl zamieszkujący na tych terenach, o którego przestrzeń do życia walczyli członkowie inicjatywy. Znakiem rozpoznawczym ruchu stały się modraszkowe skrzydła, do których wykonania i noszenia zachęcali inicjatorzy akcji. O przyczynach podjęcia działań organizatorzy pisali na swoim blogu:

Dlaczego motylki modraszki? Bo to one właśnie zamieszkują sporną łąkę między ulicą Wyłom i św. Jacka. Motylek jest dla nas pretekstem i symbolem. Działamy bez instytucji, nasz budżet wynosi 0 PLN, mamy tekturowe skrzydła i poczucie, że trzeba głośno wypowiedzieć się w sprawie Zakrzówka. Chcemy mieć Zakrzówek bez osiedla i drogi biegnącej tuż przy samym jeziorze. [...] Teraz ważą się losy modraszkowej łąki - czy będzie terenem budowlanym, czy zielenią publiczną [Kłos, 2011].

Przykład ten jest ilustracją organizacji w pierwszej fazie życia; dominującymi cechami Kolektywu są nieformalność i działanie bez struktur, z silną pozycją lidera-założyciela. Organizacja bardzo aktywnie gromadziła zasoby, utrwalając swoje miejsce w układzie sił skupionych wokół tego tematu. Ważnym aspektem, na który zwrócili uwagę aktywiści, była dyskusja nad alternatywnym wykorzystaniem 
tej przestrzeni (utworzenie miejskich terenów zielonych), ale również problemem nielegalnego korzystania z niezabezpieczonej przestrzeni wyrobiska przez mieszkańców. Liczne wypadki, niektóre również ze skutkiem śmiertelnym, zintensyfikowały dyskusje aktywistów i włodarzy miasta. Modraszki pojawiały się na licznych pikietach przed magistratem, na jednej z sesji rady miasta błękitne skrzydełka zostały wręczone prezydentowi Jackowi Majchrowskiemu. Spór o tereny trwa nadal. Wiele organizacji walczy o respektowanie obowiązującego od 2012 roku miejscowego planu zagospodarowania przestrzennego obszaru Park Zakrzówek oraz przyłączenie do tego planu również prywatnych terenów między ulicami Wyłom i św. Jacka. W projektach budżetu obywatelskiego pojawiły się liczne propozycje grupy Zielony Zakrzówek (kąpielisko, trasa rowerowa, siłownia na wolnym powietrzu). Ostatnie negocjacje $\mathrm{z}$ inwestorami wskazują jednak na postępowanie procedur mających na celu sfinalizowanie umowy z portugalskim deweloperem. Cecylia Malik po raz kolejny zaangażowała się w nagłaśnianie i komentowanie sprawy: „Miasto kupuje od dewelopera skały i wodę za 26 milionów (tam i tak nie da się budować) i pozwala budować na modraszkowej łące, o którą robiliśmy protesty. Za 26 milionów mogli kupić łąkę i w tedy cały Zakrzówek byłby parkiem" [Rąpalski, 2015] Niezależnie od przyszłego zakończenia sporu, działania ruchu w znaczący sposób wpłynęły i wciąż wpływają na bieg sprawy. Działacze nieustannie szukają alternatywnych sposobów odraczania finału negocjacji. Można podjąć dyskusję co do oceny zasadności działań Kolektywu i innych skupionych wokół Zakrzówka podmiotów, jednak na pewno nie należy odmawiać im roli, jaką odegrały w walce o zmianę postrzegania tych terenów w planach rozwoju miasta. O skuteczności podjętych wysiłków będzie można wnioskować dopiero po zakończeniu całej sprawy.

\section{Kraków Przeciw Igrzyskom}

Kraków Przeciw Igrzyskom przeszedł drogę od inicjatywy obywatelskiej, powstałej w 2013 roku, aż do oficjalnego komitetu wyborczego, który w wyborach parlamentarnych w 2015 roku startował z list wyborczych partii Razem [Kraków Przeciw Igrzyskom]. Powstanie tej inicjatywy było związane bezpośrednio $\mathrm{z}$ kandydaturą miasta $\mathrm{w}$ konkursie na organizację Zimowych Igrzysk Olimpijskich w 2022 roku. Prace nad zgłoszeniem Krakowa rozpoczęto w lipcu 2012 roku, z inicjatywy posłanki Platformy Obywatelskiej, Jagny Marczułajtis-Walczak i profesora krakowskiej Akademii Wychowania Fizycznego, Szymona Krasickiego. Projekt zakładał szeroką współpracę między Krakowem i Katowicami, Oświęcimiem, Myślenicami, Zakopanem, Kościeliskiem i Bukowiną Tatrzańską. Z czasem partnerami projektu stał się również region tatrzański po stronie słowackiej, gdzie planowano rozegrać część konkurencji, między innymi freestyle i kombinację alpejską. W samym Krakowie miało powstać miasteczko olimpijskie i tor do łyżwiarstwa szybkiego. Zakopane miało sfinansować powstanie $20 \mathrm{~km}$ tras narciarstwa biegowego i modernizację skoczni narciarskich, 
a w Myślenicach przygotowywano inwestycję budowy toru bobslejowego i saneczkowego. Projekt kandydatury zyskiwał aprobatę - od szczebla samorządowego aż po najwyższe władze rządowe (ówczesny premier Donald Tusk zaaprobował kandydaturę Krakowa już we wrześniu 2012 roku). Całość projektu zakładała bardzo złożoną współpracę między regionami i ze stroną słowacką. Liczba planowanych inwestycji była imponująca i miały dotyczyć nie tylko infrastruktury sportowej, ale również noclegowej i drogowo-komunikacyjnej. Oprócz Krakowa, swoje kandydatury przygotowywały władze Ałma-Aty w Kazachstanie, chińskiego Pekinu, Oslo w Norwegii i ukraińskiego Lwowa.

Od początku prac nad kandydaturą powracającym wątkiem była kwestia doprecyzowania kwoty, jaką pochłonie organizacja tak rozległego wydarzenia. Szefowie komitetu nie byli w stanie podać wysokości wydatków, których składników przybywało z każdym miesiącem. Bardzo skromna polityka informacyjna organizatorów ściągnęła uwagę licznych środowisk, które coraz głośniej donosiły o nadużyciach i niejasnościach związanych z pracami komitetu. Dla przykładu projekt kandydatury przygotowała szwajcarska firma Event Knowledge Services za kwotę $22 \mathrm{mln}$ zł, koszty poniesione na przygotowanie logo i strony internetowej wyniosły około 150 tys. zł [Żurawik, 2014]. Przedstawiciele organizatorów pojechali również na szkolenia do Soczi podczas trwającej tam zimowej olimpiady. Zadaniem delegacji było zdobycie umiejętności z obsługi procedur, których dopełnienie już wcześniej zostało zlecone zewnętrznej firmie za kwotę 3,4 mln zł. Koszt wyjazdu opiewał na 60 tys. zł [Serafin, 2014]. Dopiero po dwóch latach przygotowań, w marcu 2014 roku, władze komitetu organizacyjnego zdecydowały się na konsultacje społeczne [Kraków walczy o..., 2014].

W październiku 2013 roku oficjalnie zawiązana została inicjatywa Kraków Przeciw Igrzyskom, której członkowie skupieni wokół Tomasza Leśniaka (ówczesnego radnego Rady Miasta Krakowa, później także kandydata na stanowisko prezydenta miasta) regularnie śledzili proces aplikacyjny i działania władz komitetu. Bardzo intensywnie nagłaśniali też sprawę na portalu społecznościowym, co w znaczący sposób przesądziło o zgromadzeniu tak dużego poparcia społecznego. Media dotarły do informacji odnośnie do osób zatrudnianych przy organizacji igrzysk, posądzając o nepotyzm przewodniczącą komitetu. Ponadto prowokacja dziennikarska ujawniła działania męża Jagny Marczułajtis-Walczak, który oferował gratyfikację finansową w zamian za przychylne teksty prasowe o kandydaturze Krakowa [Salamon, 2014]. Te wszystkie okoliczności wzmocniły pozycję inicjatywy KPI, pozwalając na walkę o organizację referendum w tej sprawie. Niedługo później nastąpiła zmiana na stanowisku przewodniczącego komitetu. Wniosek o organizację referendum został przegłosowany. Miasto zorganizowało kampanię promocyjną, sygnując ją takimi hasłami jak „Igrzyska to metoda na korki”, „Igrzyska to metoda na smog”, ,Igrzyska to 35 tys. miejsc pracy”. KPI odpowiedziało kampanią informacyjną, pokazującą koszty wybranych elementów budżetu Igrzysk w zestawieniu z pozycjami budżetu Krakowa na takie cele jak: rehabilitacja osób niepełnosprawnych, infrastruktura rowerowa, przeciwdziałanie przemocy, walka ze smogiem czy schroniska dla zwierząt. Ponadto publikowało wypowiedzi związane z organizacją igrzysk, między innymi prof. Leszka 
Balcerowicza, wicepremier Elżbiety Bieńkowskiej czy prof. Politechniki Krakowskiej Dariusza Kozłowskiego.

24 maja 2015 roku odbyło się referendum, w którym prawo głosu miało 585140 osób. W głosowaniu wzięło udział 210441 osób (35,96\%), co oznacza, że referendum było ważne. Mieszkańcy miasta opowiedzieli się przeciw organizacji zimowych igrzysk stosunkiem głosów 69,72\% do 30,28\% [Wyniki referendum, 2015]. Działalność inicjatywy Kraków Przeciw Igrzyskom jest przykładem największej zakończonej sukcesem ingerencji w obrane kierunki polityki rozwoju terytorialnego miasta. Sposób działania, wykorzystywane kanały informacyjne, dysponowanie funduszami na kampanię promocyjną i ukonstytuowanie się grupy zarządzającej działaniami inicjatywy świadczą o funkcjonowaniu organizacji na poziomie drugiej fazy cyklu życia organizacji. Wejście KPI na ten pułap zwielokrotniło szanse organizacji na realizację postulatów i pozwoliło stworzyć pełnowymiarową opozycję dla działań komitetu konkursowego. Ten przypadek jest również dobrym przykładem obrazującym siłę współpracy i uzupełniania się różnych grup gremium opiniującego. W tym przypadku olbrzymią rolę dla powodzenia działań KPI odegrały prasa i lokalne portale informacyjne.

\section{Krakowski Alarm Smogowy}

Jakość powietrza w Krakowie, w szczególności w miesiącach zimowych, jest problemem, z którym miasto próbuje walczyć od wielu lat. Kraków pod tym względem jest jednym z najbardziej zanieczyszczonych miejsc w Europie. Zgromadzone dane wskazują na silny związek przekraczania norm jakości powietrza z trwaniem sezonu grzewczego [Skad tyle rakotwórczego...]. Niestety spora część budynków w centrum Krakowa wciąż jest ogrzewana piecami węglowymi. Krakowski Alarm Smogowy był inicjatywą obywatelską, która zawiązała się w proteście wobec braku skutecznych działań samorządu mających prowadzić do polepszenia jakości powietrza. Pierwszym z kroków podjętych przez inicjatywę było przekazanie władzom wojewódzkim petycji z apelem o podjęcie działań zapobiegawczych [Petycja]. Organizowano liczne strajki i pikiety mające zwrócić uwagę włodarzy miasta na narastający problem. Kwestia zanieczyszczenia powietrza zaczęła również odbijać się na wizerunku miasta, które od wielu lat stanowi jedną z najważniejszych destynacji zagranicznych wycieczek.

W 2013 roku inicjatorzy ruchu zdecydowali się na zarejestrowanie stowarzyszenia Krakowski Alarm Smogowy. Rozpoczęli kampanią informacyjną Kraków chce oddychać oraz No smoking, please, stworzoną dzięki współpracy zaoferowanej KAS nieodpłatnie przez agencję Schulz Brand Friendly [Kraków chce oddychać]. W mieście pojawiła się seria bilboardów zachęcających do podpisania petycji z prośbą o wprowadzenie zakazu palenia węglem i paliwami stałymi w piecach domowych. W tym samym roku zainicjowano kolejną kampanię, która powstała na podstawie komentarzy mieszkańców zamieszczonych pod wspomnianą petycją. Serię czarno-białych plakatów przygotowali krakowscy graficy. Charakterystycznym 
motywem kampanii był gołąb w masce przeciwgazowej [Apel na citylightach]. Kampania Kraków bez smogu miała wymiar edukacyjny. Był to kolejny projekt poprowadzony przez agencję Schulz Brand Friendly. Przedstawiał korzyści wynikające z wyeliminowania źródeł smogu, zarówno zdrowotne, jak i finansowe. Serii plakatów towarzyszył spot wyświetlany w kinach Cinema City. Organizacja włączyła się również w aktywne działania na rzecz uchwalenia pierwszej krakowskiej uchwały antysmogowej. W 2014 roku została ona jednak uznana przez Wojewódzki Sąd Administracyjny za niezgodną z prawem. Według sądu, żadna z ustaw nie dawała prawa do wprowadzenia takiego zakazu krakowskim radnym. Wyrok ten potwierdził Naczelny Sąd Administracyjny, który odrzucił skargi kasacyjne złożone między innym przez Sejmik Województwa i Krakowski Alarm Smogowy. Organizacja stała się partnerem działaczy samorządowych, z którymi wspólnie spotkali się w Kancelarii Prezydenta Rzeczpospolitej Polskiej Andrzeja Dudy w sprawie nowelizacji Ustawy Prawo Ochrony Srodowiska [Karkoszka, 2015]. Prezydent podpisał poprawkę artykułu 96, co otworzyło możliwość ponownego poddania uchwały pod głosowanie. Na początku stycznia 2016 roku Sejmik Województwa przegłosował przyjęcie uchwały, w związku z czym od 2019 roku w Krakowie będzie obowiązywać całkowity zakaz palenia węglem. Krakowski Alarm Smogowy niedługo po pierwszym przyjęciu uchwały zainicjował kolejną kampanię: Weź dotację, wymień piec. Bilboardy, strona internetowa, jak również kampania w telewizji M, nadawanej w pojazdach Miejskiego Przedsiębiorstwa Komunikacyjnego w Krakowie, została stworzona przy wsparciu i dofinansowaniu Wojewódzkiego Funduszu Ochrony Środowiska i Gospodarki Wodnej w Krakowie. Akcja ta jest kontynuowana, mieszkańcy mogą uzyskać pomoc w wypełnieniu wniosku o dopłatę do wymiany pieca węglowego, znaleźć wszystkie potrzebne informacje, ale także przeczytać o korzyściach płynących ze zmiany źródeł ogrzewania [Weź dotację...]. Organizacja wciąż prowadzi kontrolę jakości powietrza w mieście, organizuje wydarzenia promujące walkę ze smogiem. KAS jest przykładem organizacji znajdującej się w trzeciej fazie cyklu życia. Świadczą o tym świadomie tworzone struktury, formalny charakter organizacji, profesjonalizacja działań oraz zyskanie ugruntowanej pozycji w środowisku. Taki poziom rozwoju pozwala na pełne włączenie się w procesy kształtowania rozwoju terytorialnego jako liczący się partner działań.

\section{Podsumowanie i wnioski}

Przedstawione przykłady są jedynie skromną reprezentacją dużej liczby podmiotów, które działają na rzecz kształtowania rozwoju Krakowa. Jest ono miastem, w którym wzrost uczestnictwa obywateli w procesach zogniskowanych wokół rozwoju terytorialnego i kształtowania polityki regionalnej jest bardzo widoczny. Świadome uczestnictwo społeczności lokalnych staje się wartościowym źródłem informacji o potrzebach i preferowanych kierunkach rozwoju; zarówno organizacje pozarządowe, jak i inicjatywy obywatelskie stanowią pewnego 
rodzaju reprezentację lokalnych środowisk. Przedstawione przykłady organizacji wskazują, iż wraz ze wzrostem stopnia zaawansowania fazy cyklu życia podmiotu rośnie złożoność jego działań. Aktywność Kolektywu Modraszek, będącego w pierwszej fazie cyklu życia organizacji, wyraźnie cechują rewolucyjny, doraźny charakter inicjatyw, mocna pozycja aktywnego lidera oraz nieformalność struktur i charakteru przynależności. Inicjatywa Kraków Przeciw Igrzyskom, organizacyjnie znajdująca się w drugiej fazie cyklu życia, wykształciła podstawowe struktury wewnętrzne oraz zgromadziła fundusze na działalność, co doprowadziło do systematyzacji działań i formułowania podstawowych założeń strategicznych. Osoba lidera wspomaga identyfikację działań, jednak właściwe zadania są delegowane między szersze grono współpracowników. Stowarzyszenie Krakowski Alarm Smogowy odeszło do bezpośredniej reprezentacji działań przez lidera, skupia się na promowaniu wizerunku całej organizacji. Posiada w pełni wykształcone struktury organizacyjne, które umożliwiają kompleksowe i profesjonalne uczestnictwo w procesach zarządzania rozwojem terytorialnym. Cechy te pozwalają jednoznacznie umieścić to stowarzyszenie w trzeciej fazie cyklu życia organizacji.

Im bardziej profesjonalne i merytoryczne są podejmowane działania, tym bardziej dojrzały jest podmiot inicjujący. Dojrzałość organizacyjna pozwala na wspieranie i uzupełnianie działań władz samorządowych, na zasadach równorzędnego partnerstwa. Wspieranie takich inicjatyw pozwala także na tworzenie silnego, trwałego i skutecznego frontu wspólnych starań samorządu i mieszkańców. Przywołane przykłady wskazują, że działania obywatelskie dotyczące rozwoju miasta najczęściej łączą się z formą sprzeciwu wobec zastanej sytuacji. Dla strony samorządowej taka działalność może być problematyczna. Warto jednak się zastanowić, czy inicjatywy podejmowane przez organizacje obywatelskie nie powinny być odczytywane jako cenne źródła informacji zwrotnych o przeprowadzonych lub zaniechanych działaniach. Jednak niezależnie od świadomości istnienia takiego źródła oceny, przytoczone przykłady świadczą o tym, że zaangażowanie strony społecznej w tworzenie i wdrażanie polityki rozwoju regionalnego może przesądzić o sukcesie lub porażce obranego kierunku zmian.

\section{Bibliografia}

Bogacz-Wojtanowska E. (2006), Zarzadzanie organizacjami pozarzadowymi na przykładzie stowarzyszeń krakowskich, Wydawnictwo Uniwersytetu Jagiellońskiego, Kraków.

Heffner K. (2008), Strategie rozwoju regionalnego i lokalnego [w:] Z. Strzelecki (red.), Gospodarka lokalna i regionalna, Wydawnictwo Naukowe PWN, Warszawa.

Noworól A. (1998), Instrumenty zarządzania rozwojem miasta, Instytut Gospodarki Przestrzennej i Komunalnej Oddział w Krakowie, Kraków.

Noworól A. (2007), Planowanie rozwoju terytorialnego w skali lokalnej i regionalnej, Wydawnictwo Uniwersytetu Jagiellońskiego, Kraków. 
Srokosz J. (2007), Grupy nacisku i zjawisko lobbingu we wspótczesnych państwach [w:] M. Sadowski, Studia Erasmiana Wratislaviensia, Wrocław.

\section{Źródła elektroniczne}

Apel na citylightach, http://www.krakowskialarmsmogowy.pl/onas/index/id/25 [dostęp: 14.02.2016].

Bazy NGO, http://www.bazy.ngo.pl/ [dostęp: 29.12.2015].

Główny Urząd Statystyczny (2015), Społeczeństwo informacyjne w Polsce w 2015 r. stat.gov.pl/download/gfx/portalinformacyjny/pl/defaultaktualnosci/5497/2/5/1/spoleczenstwo_informacyjne_w_polsce_2015_-_notatka.pdf [dostęp: 18.02.2016]

Karkoszka M. (2015), NSA: uchwała antysmogowa niezgodna z prawem, http://www.gazetakrakowska.pl/artykul/8416476,nsa-uchwala-antysmogowa-niezgodna-z-prawem,id,t. html [dostęp: 20.02.2016].

Kłos K. (2011), Zaczynamy!, http://modraszekkolektyw.blogspot.com/2011/05/zaczynamy_15.html [dostęp: 02.11.2015].

Kraków chce oddychać, http://www.krakowskialarmsmogowy.pl/onas/index/id/24 [dostęp: 14.02.2016].

Kraków Przeciw Igrzyskom, $O$ KPI, www.krakowprzeciwigrzyskom.pl [dostęp: 25.10.2015].

Petycja, http://www.krakowskialarmsmogowy.pl/onas/index/id/100 [dostęp: 14.02.2016].

Kraków walczy o zimowe Igrzyska. Kalendarium, http://www.radiokrakow.pl/nasze-akcje/ krakow-walczy-o-zimowe-igrzyska-kalendarium/ [dostęp: 29.10.2015].

Rąpalski P. (2015), Kraków. Zakrzówek. Leca „szuje” ze strony artystki-ekologa, http:// krakow.naszemiasto.pl/artykul/krakow-zakrzowek-leca-szuje-ze-strony-artystki-ekologa,3543790,art,t,id,tm.html [dostęp: 17.02.2016].

Salamon P. (2014), Prowokacja LOVEKRAKOW.PL: komitet konkursowy ZIO to siedlisko patologii, http://lovekrakow.pl/aktualnosci/prowokacja-lovekrakowpl-komitet-konkursowy-zio-siedlisko-patologii_5528.html [dostęp: 20.02.2016].

Serafin D. (2014), Kraków chce Igrzysk. Dlatego wyśle do Soczi wycieczkę, http://www. gazetakrakowska.pl/artykul/3316836,krakow-chce-igrzysk-dlatego-wysle-do-soczi-wycieczke,id,t.html [dostęp: 20.02.2016].

Skąd tyle rakotwórczego benzo[a]pirenu w krakowskim powietrzu?, http://www.krakowskialarmsmogowy.pl/smog/szczegoly/id/91 [dostęp: 20.02.2016].

Weź dotację, wymień piec, http://www.krakowskialarmsmogowy.pl/onas/index/id/149 [dostęp: 14.02.2016].

Wyniki referendum (2015), https://www.bip.krakow.pl/?dok_id=60751 [dostęp: 20.02.2016].

Żurawik M. (2014), Igrzyska w Krakowie. Miasto płaci 150 tys. za logo i stronę. Czy to dużo?, http://wyborcza.biz/biznes/1,100896,15673805,Igrzyska_w_Krakowie_Miasto_placi_150_tys_zl_za_logo.html [dostęp: 20.02.2016]. 